\title{
Sporadic bilateral carotid body paragangliomas
}

\author{
Sreekanth Amith, Bachavarahalli Sriramareddy Rajesh, Souradeep Dutta (i) , \\ Amaranathan Anandhi
}

Department of Surgery, Jawaharlal Institute of Postgraduate Medical Education and Research, Puducherry, India

\section{Correspondence to}

Dr Amaranathan Anandhi; anandhiramesh76@yahoo.in

Accepted 13 July 2020
Check for updates

(c) BMJ Publishing Group Limited 2020. No commercial re-use. See rights and permissions. Published by BMJ.

To cite: Amith S, Rajesh BS, Dutta $\mathrm{S}$, et al. BMJ Case Rep 2020;13:e237668. doi:10.1136/bcr-2020237668

\section{DESCRIPTION}

A 57-year-old woman presented with complaints of swellings on both sides of her neck for the past 4 years which were gradually increasing in size. They were painless and she did not complain of any difficulty in breathing or swallowing. She had no complaints of blushing or palpitations in the past. She did not have any history of residency in hilly areas or exposure to chronic hypoxic conditions. There were no other swellings in the body.

On examination, a $3 \times 2 \mathrm{~cm}$ hard, round and mobile swelling was noted on the right side and a $2 \times 3 \mathrm{~cm}$ hard, mobile swelling on the left side. Vertical mobility of both masses was restricted compared with horizontal mobility (Fontaine sign). ${ }^{1}$ Oral examination did not reveal any pharyngeal wall swelling. Cranial nerve examination was normal. Other system examinations were unremarkable.

No abnormalities were noted on chest X-ray or ECG. Duplex ultrasound of the neck revealed vascularised hypoechoic masses at the carotid artery bifurcation on either side. Intravenous contrastenhanced CT of the neck and cerebral region showed bilateral, intensely enhancing soft tissue density lesions in (both) carotid space of $4 \times 3 \times 3 \mathrm{~cm}$ in size in the left carotid space and a similar lesion of $1.5 \times 1.5 \mathrm{~cm}$ in size in the right carotid space (figure 1A-C). MRI of the head and neck showed lesion in both the carotids with characteristic salt and pepper appearance (figure 1D).

Abdominal ultrasonography, urine vanillylmandelic acid, and plasma epinephrine and norepinephrine levels were normal. There was no suggestive family history of neck masses. No further genetic evaluation could be done due to unavailability of such facilities in the hospital. The patient was taken up for excision of bilateral carotid body lesions under general anaesthesia and the postoperative specimen was sent for histopathological examination, which

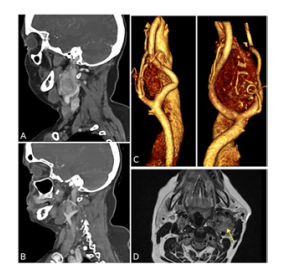

Figure 1 (A) CT angiography showing splitting of both carotids due to left carotid paraganglioma. (B) $\mathrm{CT}$ angiography showing splitting of both carotids due to right carotid paraganglioma. (C) Three-dimensional reconstruction of both the carotid body paragangliomas. (D) T1-weighted MRI showing salt and pepper appearance (arrow) of left carotid body paraganglioma.

\section{Patient's perspective}

I am an agricultural laborer and I don't often feel sick. I was having swelling in the sides of neck for last fouryears, initially only in the left, and then also in the right. They were slowly growing. When the right sided swelling appeared in the last 6 months, I took medical advice from the primary health centre, and I was referred to the present hospital where Dr. Anandhi has examined me. Following some scans, the doctor informed me that I had a tumor sort of a thing in my neck region and that is the reason for swelling. I was worried that it might be cancer and I was in serious trouble. But immediately the doctor had reassured me that it was a localized lesion and the chances of the disease being spread to other areas is very less. She said we will have to do two more tests to know more about the disease. One test was longer than the other test and I was worried a little at the loud noises the machine had made during the scan. The technician was talking to me and helped me keep calm during the procedure. After the report, Dr Anandhi has said that the diagnosis was nearly confirmed. I was explained about the surgical procedure and the risks associated. I gave my consent to the procedure. After I regained consciousness after the surgery I saw dressings over neck. I had some pain and discomfort on the first day. I recovered fast and I was discharged after 3 days. I was overwhelmed by the care given by the doctors and nursing staff in the hospital and thank them all.

\section{Learning points}

- Occurrence of sporadic bilateral carotid body paragangliomas is rare.

- Preoperative fine needle aspiration cytology of the tumour is discouraged owing to its highly vascular nature.

- CT angiography is sufficient to establish the diagnosis and surgical excision with or without vascular reconstruction.

confirmed the diagnosis of carotid body paragangliomas. The postoperative period was uneventful, and the patient was discharged in a stable condition.

Paragangliomas of bilateral carotid glands account for $3 \%$ of all paragangliomas in the body. ${ }^{2}$ They manifest as slow-growing, painless masses located mostly at the hyoid bone level, anterior to 
the sternocleidomastoid muscle. Occasionally carotid bruit can be heard, which was absent in our case. Most of the sporadic cases occur as unilateral masses, but familial tumours tend to occur bilaterally. The vascular nature of this tumour stands as a potential risk for an uncontrolled bleeding if an incisional biopsy is attempted. CT angiography forms the mainstay of diagnosis of carotid body tumour, which shows a mass at the carotid artery bifurcation that causes splaying of the internal and external carotid arteries (Lyre sign). This should be differentiated from the pseudo-Lyre sign, which is caused by paraganglioma arising from the vagus nerve. ${ }^{3}$

Preoperative embolisation with polyvinyl alcohol and gel foam can be used for highly vascular tumours larger than $5 \mathrm{~cm} .{ }^{4}$ However, a few reports state an increased incidence of complications such as cerebral ischaemia and cranial nerve palsies with this embolisation. ${ }^{5}$ Surgical excision of the tumour with vascular reconstruction is the main treatment modality in these cases. In cases of recurrence or large malignant lesions, radiotherapy can also be considered as a modality of treatment. ${ }^{6}$

Twitter Bachavarahalli Sriramareddy Rajesh @rajeshbs89 and Souradeep Dutta @ souradeep

Contributors SA, SD: conception and design, acquisition of data, or analysis and interpretation of data. SA, BSR, AA: drafting the article and revising it critically for important intellectual content, and involved in patient care. SD and AA approved the final version. All authors contributed equally to drafting the article.

Funding The authors have not declared a specific grant for this research from any funding agency in the public, commercial or not-for-profit sectors.

Competing interests None declared.

Patient consent for publication Obtained.

Provenance and peer review Not commissioned; externally peer reviewed.

\section{ORCID iDs}

Souradeep Dutta http://orcid.org/0000-0002-1600-3439

Amaranathan Anandhi http://orcid.org/0000-0001-8009-0445

\section{REFERENCES}

1 Sanlı A, Öz K, Ayduran E, et al. Carotid body tumors and our surgical approaches. Indian J Otolaryngol Head Neck Surg 2012;64:158-61.

2 Singh A, Subash A, Panda NK, et al. Bilateral carotid body tumor in a 13-year-old child: our experience 2017;5:4.

3 Nash R, Farrell R. Pseudo-lyre sign. J Surg Case Rep 2011:2011:2.

4 Hallett JW, Nora JD, Hollier LH, et al. Trends in neurovascular complications of surgical management for carotid body and cervical paragangliomas: a fifty-year experience with 153 tumors. J Vasc Surg 1988;7:284-91

5 Rao AB, Koeller KK, Adair CF. From the Archives of the AFIP. paragangliomas of the head and neck: radiologic-pathologic correlation. armed forces Institute of pathology. Radiographics 1999;19:1605-32.

6 Gerosa M, Visca A, Rizzo P, et al. Glomus jugulare tumors: the option of gamma knife radiosurgery. Neurosurgery 2006;59:561-9. discussion 561-569.

Copyright 2020 BMJ Publishing Group. All rights reserved. For permission to reuse any of this content visit

https://www.bmj.com/company/products-services/rights-and-licensing/permissions/

BMJ Case Report Fellows may re-use this article for personal use and teaching without any further permission.

Become a Fellow of BMJ Case Reports today and you can:

- Submit as many cases as you like

- Enjoy fast sympathetic peer review and rapid publication of accepted articles

- Access all the published articles

- Re-use any of the published material for personal use and teaching without further permission

Customer Service

If you have any further queries about your subscription, please contact our customer services team on +44 (0) 2071111105 or via email at support@bmj.com.

Visit casereports.bmj.com for more articles like this and to become a Fellow 